DOI:10.22337/2587-9618-2019-15-4-14-24

\title{
ABOUT "LEGITIMIZATION" OF NUMERICAL MODELLING OF WIND IMPACTS ON BUILDINGS AND STRUCTURES IN DESIGN CODES
}

\author{
Alexander M. Belostotsky 1, 2, 3, 4, 5, 6, Pavel A. Akimov 1, 2,3, ${ }^{\text {, Irina N. Afanasyeva }}{ }^{\text {1,8 }}$ \\ ${ }^{1}$ Scientific Research Center "StaDyO", Moscow, RUSSIA \\ ${ }^{2}$ Tomsk State University of Architecture and Civil Engineering, Tomsk, RUSSIA \\ ${ }^{3}$ Peoples' Friendship University of Russia, Moscow, RUSSIA \\ ${ }^{4}$ Russian University of Transport (MIIT), Moscow, RUSSIA \\ ${ }^{5}$ Perm National Research Polytechnic University, Perm, RUSSIA \\ ${ }^{6}$ Irkutsk National Research Technical University, Irkutsk, RUSSIA \\ ${ }^{7}$ Russian Academy of Architecture and Building Sciences, Moscow, RUSSIA \\ ${ }^{8}$ University of Florida, Gainesville, USA
}

\begin{abstract}
The distinctive paper is detoded to problem of "legitimization" of numerical modelling of wind loads and impacts on buildings and structures. General information about computational fluid dynamics (CFD) and its development prospects is presented. The main advantages and disadvantages of numerical simulation compared with tests in wind tunnels (wind tunnel tests) are considered. Besides, information about the second modification of corresponding Russian design codes (SP 20.13330.2016 "SNiP 2.01.07-85* Loads and effects") is provided. Prospects for the further development of numerical modelling and its applications for solution of problems of construction aerodynamics are given.
\end{abstract}

Keywords: numerical modelling, wind loads, wind impacts, wind tunnels, construction aerodynamics, computational fluid dynamics, design codes

\section{О «ЛЕГИТИМИЗАЦИИ» В СТРОИТЕЛЬНЫХ НОРМАХ И ПРАВИЛАХ ЧИСЛЕННОГО МОДЕЛИРОВАНИЯ ВЕТРОВЫХ ВОЗДЕЙСТВИЙ НА ЗДАНИЯ И СООРУЖЕНИЯ}

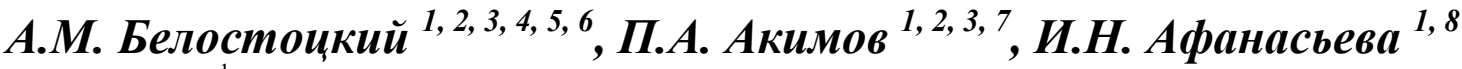 \\ ${ }^{1}$ Научно-исследовательский центр СтаДиО, г. Москва, РОССИЯ \\ 2 Томский государственный архитектурно-строительный университет, г. Томск, РОССИЯ \\ 3 Российский университет дружбы народов, г. Москва, РОССИЯ \\ ${ }^{4}$ Российский университет транспорта (МИИТ), г. Москва, РОССИЯ \\ ${ }^{5}$ Пермский национальный исследовательский политехнический университет, г. Пермь, РОССИЯ \\ ${ }^{6}$ Иркутский национальный исследовательский технический университет, г. Иркутск, РОССИЯ \\ ${ }^{7}$ Российская академия архитектуры и строительных наук, г. Москва, РОССИЯ \\ ${ }^{8}$ Университет Флориды, г. Гейнсвилл, США
}

\begin{abstract}
Аннотация: Настоящая статья посвящена актуальным вопросам, связанным с «легитимизацией» численного моделирования ветровых нагрузок и воздействий. В работе приводятся некоторые общие сведения о развитии методов вычислительной аэродинамики и их приложений в строительной сфере. Рассмотрены основные преимущества и недостатки численного моделирования по сравнению с испытаниями в аэродинамических трубах. Кроме того, приведены сведения об изменении №2 свода правил (СП) 20.13330.2016 «СНиП 2.01.07-85* Нагрузки и воздействия». В заключение указаны перспективы дальнейшего развития численного моделирования для решения задач строительной аэродинамики.
\end{abstract}

Ключевые слова: численное моделирование, ветровые нагрузки, ветровые воздействия, аэродинамические трубы, строительная аэродинамика, вычислительная аэрогидродинамика, строительные нормы и правила 


\section{GENERAL INFORMATION}

Analysis and design of unique buildings, structures and complexes is traditionally complicated, in particular, by the fact that the current design codes do not contain recommendations on the determination of values of aerodynamic coefficients for original in shape and large-sized construction objects (including majority of highrise buildings) [1-8]. In addition to the substantially approximate nature of the corresponding engineering approaches, both Russian and a number of foreign design codes do not consider options for the location of such buildings and structures in buildings and the interference of buildings and structures. In other words, these approaches are suitable only for buildings and structures with a relatively simple shape, low and medium height, located in conditions of sparse development. For unique buildings, structures and complexes (especially located in conditions of relatively dense development) more accurate (refined, high-presicion) methods are needed. In such cases, in Russian and some foreign design codes it was proposed to use the results of tests of large-scale models in specialized wind tunnels, allowing reproducing the atmospheric boundary layer. At the same time, in accordance with numerous research works of Russian and foreign scientists published in recent years, it was noted that computational fluid dynamics (CFD) [1], which has been developing rapidly in recent decades, in the future can be considered as an effective alternative of tests in wind tunnels for solution of problems of determination of wind loads and impacts on buildings and structures, assessment of pedestrian comfort and analysis of air pollution. A certain confidence in such assessments was also given by the continuous rapid development of corresponding hardware and software.

Application of methods of computational aerodynamics methods (numerical modeling) allows researcher obtaining results with an accuracy equal to or greater than accuracy, provided by tests in wind tunnels, associated, as a rule, with the need to attract significant resources (includ- ing financial resources). Corresponding modern software is characterized by advanced user interface, powerful and convenient preprocessor and postprocessor, sophisticated tools for monitoring and analysis of results.

\section{THE MAIN ADVANTAGES OF NUMERICAL SIMULATION IN COMPARISON WITH TESTS IN WIND TUNNELS}

\subsection{Automatic determination of computa- tional parameters at specified subdomains of the computational domain.}

As is known, when testing in a wind tunnel, it is necessary to place measuring equipment to determine the wind speed at a specific point. Application of methods of computational aerodynamics methods allows computing of velocity values within numerical modelling.

\subsection{The relative simplicity of making chang- es to design solutions.}

The software that implements the methods of computational aerodynamics allows efficient interaction with CAD applications; modifications of design solutions can be introduced as soon as possible. Obviously, within physical modelling, the same changes are associated with significantly larger time and labor costs, especially in situations when changes to design solutions are made after a considerable time and after the initial tests in wind tunnel or in conditions when the corresponding wind tunnel is busy in other projects.

\subsection{Economic efficiency.}

Application of method of computational aerodynamics is normally associated with significantly lower financial costs and time expenditures in comparison to conducting tests in wind tunnels.

\subsection{Visual clarity of results.}

Software that implements computational aerodynamics methods allows researcher simply and 
clearly visualize corresponding results. Photos of tests in wind tunnels, on the contrary, are not so informative.

\subsection{Universality.}

It is rather complicated to solve problems dealing with determination of the wind direction, the level of concentration of pollutants, radiation level, etc. by the tests in wind tunnels. Methods of computational aerodynamics are more flexible and therefore more convenient in this connection.

\subsection{The disadvantages of wind tunnels.}

As is known, testing in wind tunnels requires large-sized expensive equipment, which is produced by a relatively small number of multinational firms and foreign research and educational centers. Numerical modelling can be performed by a large number of firms, research and educational centers, which in many cases have deeper and more reliable values dealing with the meteorological situation in the construction area.

\section{THE MAIN DISADVANTAGES OF NUMERICAL SIMULATION IN COMPARISON WITH TESTS IN WIND TUNNELS}

\subsection{Lack of standard approach status.}

Numerical modelling is a relatively new, constantly improving approach to solving the problems of construction aerodynamics, which is currently used, first of all, by advanced scientific and educational centers equipped with sophisticated software.

\subsection{Possible inaccuracy of the results.}

According to the results of corresponding research works, it was found that the results of numerical modelling in some cases may be incorrect. However, problem areas of the application are quite well known, and the corresponding error of the results, as a rule, are small and uncritical, taking into account the hypotheses introduced on the safe side (it is quite typical for engineering approaches). In addition, multiparameter verification analysis (accuracy assessments of numerical solutions in comparison with known solutions) and validation analysis (accuracy assessments of computer modelling in comparison with experimental data), including using the results of field measurements and / or wind tunnel tests.

\subsection{High qualification requirements for re- search groups.}

Numerous studies of recent years clearly show that the results of knowledge-based modelling carried out by different research groups can vary significantly, even if using the same software. Stages dealing with setting of initial data (in particular, defining parameters specifying the state of the atmosphere), boundary conditions, the choice of an approximation mesh and mathematical models (primarily turbulence models) are of paramount importance. In other words, the results of numerical modelling can be very sensitive with respect to some computational user-defined parameters of the corresponding software. In this regard, the task of development of appropriate methodological recommendations and descriptions of best practices for the application of computational aerodynamics methods in construction is particularly urgent. Besides, the practice of formal use of corresponding software (without deep knowledge of theoretical foundations of corresponding methods and algorithm, without any doubt about the correctness of the results obtained) is extremely dangerous.

\subsection{Limitations on the complexity of objects of modelling.}

The maximum dimension of the considering type of problems of numerical modelling depends on the productivity and available resources of the used hardware and software. A large wind tunnel is less limited in terms of size and complexity of models. Obviously, this drawback becomes less critical as the computer technology, universal and specialized software improve and develop. 


\subsection{Higher accuracy of results for less com- plex objects.}

It should be noted that the accuracy of the results of tests in a wind tunnel does not depend on the complexity of the geometry of the considering object. High accuracy of results of numerical modelling, for complex objects requires significant time and computational costs. Moreover, for some approaches to modelling turbulence it is not at all currently achievable.

\subsection{A significant amount of computational work associated with computing of pulsating component solutions.}

The resulting distribution of the average components of wind loads can be used for a number of practical applications, including solution of problems of pedestrian comfort analysis and air pollution analysis (when the kinetic energy of turbulence is used to analyze wind gusts). The pulsating components of the loads are important for determining the most critical locations and times.

\section{THE SECOND MODIFICATION OF CORRESPONDING RUSSIAN DESIGN CODES (SP 20.13330.2016 "SNIP 2.01.07-85 * LOADS AND EFFECTS")}

The second modification of corresponding Russian design codes (SP 20.13330.2016 "SNiP 2.01.07-85* Loads and effects") was approved by the order of the Ministry of Construction and Housing and Communal Services of the Russian Federation dated January 28, 2019 No. 49 / pr. In accordance with the third paragraph of item 11.1.7 [8] of this document [9] we have the revised corresponding text version:

"For structures with increased level of responsibility, which are specified in [1, item 48.1, part $2]$ or in note 2 , as well as in all cases not specified in B.1 (other shapes of structures, reasonable allowance for other directions of the wind flow or components of the total resistance of the body in other directions, the need to take into account the influence of nearby buildings and structures, terrain and similar cases), aerodynamic coefficients are specified in recommendations developed with allowance for item 4.7 and based on the results of

1) physical (experimental) modelling - tests in wind tunnels (appendices " $G$ " and "I");

2) mathematical (numerical) modelling of wind aerodynamics based on numerical schemes for solution of three-dimensional equations of motion of liquid and gas with adequate turbulence models implemented in modern advanced verified licensed software systems of computational fluid dynamics".

It should be noted that the link [1] in the citation is the link [10] in this paper.

In accordance to [9], the last paragraph (before the note) of item 11.2 is formulated in the new edition:

"Aerodynamic coefficients and are computed on the basis of the results of model tests of structures in wind tunnels, numerical simulation or taking into account data published in the technical literature. For separate rectangular buildings in plan terms, the values of these coefficients are specified in B.1.17".

These changes were the result of a corresponding initiative of the authors of the distinctive paper, due to the fact that recent years are associated with a fairly rapid development of computational aerohydrodynamics (computational fluid dynamics (CFD)), modification and refinement of computational technology and steadily increasing perfofmance of computers. Leading foreign research and design organizations have also increasingly begun to combine tests in wind tunnels and "numerical" experiments. In the future, the role of mathematical modelling, as experience in related fields (for example, aerospace engineering) and problems (structural mechanics) shows, will only increase. 


\section{PROSPECTS FOR THE FURTHER DEVELOPMENT OF NUMERICAL MODELLING FOR SOLUTION OF PROBLEMS OF CONSTRUCTION AERODYNAMICS}

In accordance with the recommendations of Russian and foreign researchers, numerical modelling and tests in wind tunnels can be applied for solution of problems of construction aerodynamics. Besides, in the future, the role of numerical modelling, as shown by experience in related fields (for example, aerospace) and problems (structural mechanics) ) will only increase. At the same time, high qualification of research team is a necessary condition for obtaining reliable results of numerical modelling.

It should be noted that currently researches in the field of analysis of errors in the results of numerical and physical modelling, sensitivity analysis of results, verification and validation are relevant.

It is necessary to continue the development and updating of design codes and methodological documents based on best practices in the application of methods of computational aerodynamics in the field of construction. It should be noted that such work has so far been done for steady RANS approaches to modelling turbulence based on Reynolds averaged unsteady Navier-Stokes equations, and to a much lesser extent for the large vortex modelling method (LES method). Corresponding research works will have highest priority in the future [11-49].

\section{REFERENCES}

1. Belostotsky A.M., Akimov P.A., Afanasyeva I.N. Vychislitel'naja ajerodinamika $\mathrm{v}$ zadachah stroitel'stva [Computational aerodynamics for problems of construction]. Moscow, ASV Publishing House, 2017, 720 pages.

2. Popov N.A. Nacional'noe prilozhenie k EN 1991 Evrokod 1 [National Annex to EN 1991 Eurocode 1]. Moscow, JSC Research
Center of Construction, Research Institute of Building Constructions (TSNIISK) named after V. A. Koucherenko, 2011, 99 pages.

3. Popov N.A. Rekomendacii po utochnennomu dinamicheskomu raschetu zdanij i sooruzhenij na dejstvie pul'sa-cionnoj sostavljajushhej vetrovoj nagruzki [Recommendations on the refined dynamic structural analysis with allowance for effect of the pulsation component of the wind load]. Moscow, Research Institute of Building Constructions (TSNIISK) named after V. A. Koucherenko, 2000, 45 pages.

4. Popov N.A., Bogachev D.S. Vozdejstvie vetra na vysotnye zdanija $\mathrm{v}$ uslovijah plotnoj gorodskoj zastrojki [The impact of wind on high-rise buildings in dense urban areas]. // Vestnik of JSC Research Center of Construction, 2011, No. 3-4, pp. 189-198.

5. Popov N.A., Lebedeva I.V. Izmenenie №1 k SP 20.13330.2011 "Nagruzki i vozdejstvija", Aktualizirovannoj redakcii SNiP 2.01.07-85 [The first modification to SP 20.13330.2011 "Loads and Impacts", Updated version of SNiP 2.01.07-85]. // Structural Mechanics and Analysis of Constructions, 2014, No. 2(253), pp. 67-70.

6. Popov N.A., Lebedeva I.V. Razrabotka nacional'nyh prilozhenij $\mathrm{k}$ Evrokodam EN 1990, EN 1991 s uchetom trebovanij rossijskih normativnyh dokumentov [Development of national annexes to Eurocodes EN 1990, EN 1991, with allowance for requirements of the Russian design codes. // BST: Bulletin of construction equipment, 2013, No. 2(942), pp. 37-41.

7. Popov N.A., Lebedeva I.V. Sravnitel'nyj analiz Evrokodov EN 1991 i aktualizirovannoj redakcii SNiP "Nagruzki i vozdejstvija" [Comparative analysis of Eurocodes EN 1991 and the updated edition of SNiP "Loads and Impacts"]. // Earthquake engineering. Constructions safety, 2011, No. 6, pp. 17-21.

8. SP 20.13330.2016 Nagruzki i vozdejstvija. Aktualizirovannaja redakcija SNiP 2.01.07- 
85* (s Izmeneniem No. 1) [SP 20.13330.2016 Loads and effects. Updated version of SNiP 2.01.07-85 * (with the First Modification 1). Moscow, JSC "Kodeks", 2017.

9. Izmenenie No. 2 k SP 20.13330.2016 "SNIP 2.01.07-85* Nagruzki i vozdejstvija" [The Second Modification to SP 20.13330.2016 "SNIP 2.01.07-85* Loads and impacts"]. Approved by order of the Ministry of Construction and Housing and Communal Services of the Russian Federation dated January 28, 2019 No. 49 / pr. Moscow, 2019, 21 pages.

10. Federal'nyj zakon ot 29 dekabrja 2004 g. №190-FZ “Gradostroitel'nyj kodeks Rossijskoj Federacii" [Federal Law of December 29, 2004 No. 190-FZ "Town Planning Code of the Russian Federation"].

11. Ai Z.T., Mak C.M. CFD Simulation of Flow and Dispersion Around Anisolated Building: Effect of Inhomogeneous ABL and Near-Wall Treatment. // Atmos. Environ., 2003, Vol. 77, pp. 568-578.

12. Antipin A.A., Alekhin V.N., Gorodilov S.N., Khramtsov S.V., Noskov A.S. Numerical Simulation of Wind Loads on High-Rise Buildings. // 19th Australasian Fluid Mechanics Conference, Melbourne, Australia 8-11 December 2014, 4 pages.

13. Baker C.J. Wind Engineering - Past, Present and Future. // J. Wind Eng. Ind. Aerodyn., 2007, Vol. 95(9-11), pp. 843-870.

14. Blocken B. 50 years of Computational Wind Engineering: Past, present and future. // J. Wind Eng. Ind. Aerodyn., 2014, Vol. 129, pp. 69-102.

15. Blocken B., Carmeliet J. On the Errors Associated with the Use of Hourly Data in Wind-Driven Rain Calculations on Building Facades. // Atmos. Environ., 2007, Vol. 41 (11), pp. 2335-2343.

16. British Standard, Loadings for Buildings Part 2: Code of Practice for Wind Loads, Building and Civil Engineering Sector Board, UK, 1995.
17. Castro I.P., Graham J.M.R. Numerical Wind Engineering: the Way Ahead? // Proc. Inst. Civil Eng. - Struct. Build., 1999, Vol. 134(3), pp. 275-277.

18. Cochran L., Derickson R. Aphysical Modeler's View of Computational Wind Engineering. // J. Wind Eng. Ind. Aerodyn., 2011, Vol. 99(4), pp. 139-153.

19. Cowan, Ian R. Castro, Ian P. Robins, Alan G. Numerical Considerations for Simulations of Flow and Dispersion around Buildings. // J. of Wind Eng. and Ind. Aerodynamics, 1997, Vols. 67 \& 68, pp. 535545.

20. Davenport A.G. The Missing Links. // In: Proceedings of the10th International Conference on Wind Engineering, Copenhagen, 1999, pp. 3-15.

21. Di Sabatino S., Buccolieri R., Salizzoni P. Recent Advancements in Numerical Modelling of Flow and Dispersion in Urban Areas: A Short Review. // Int. J. Environ. Pollut., 2013, Vol. 52(3-4), pp. 172-191.

22. Eurocode 1: Basis design and action on structures. Part 1: "Basis design". ENV 1991 1, // CEN, 1994, 232 pages.

23. Ferziger J.H. Approaches to Turbulent Flow Computation: Applications to Flow over Obstacles. // J. Wind Eng. Ind. Aerodyn., 1990, Vol. 35, pp. 1-19.

24. Ferziger J.H. Estimation and Reduction of Numerical Error. // FED vol. 158, In: Proceedings of the Symposium on Quantification of Uncertainty in Computational Fluid Dynamics, ASME Fluid Engineering Division, Summer Meeting, Washington DC, June20-24, 1993, pp. 1-8.

25. Ferziger J.H., Peric M. Computational Methods for Fluid Dynamics. Springer, Berlin, 1996, 356 pages.

26. Fothergill C.E., Roberts P.T. Flow and Dispersion Around Storage Tanks: A Comparison Between Numerical and Wind Tunnel Studies. // Wind \& Structures, 2002, Vol. 5, No.2-4, pp. 89-100.

27. Hanna S.R. Plume Dispersion and Concentration Fluctuations in the Atmosphere. // 
Encyclopedia of Environmental Control Technology. Air Pollution Control, 1989, Vol. 2, Gulf Publishing Company, Houston, TX, pp. 547-582.

28. Hargreaves D.M., Wright N.G. On the Use of the $\mathrm{k}-\varepsilon$ Model in Commercial CFD Software to Model the Neutral Atmospheric Boundary Layer. // J. Wind Eng. Ind. Aerodyn., 2007, Vol. 95(5), pp. 355-369.

29. Hanjalic K. Will RANS Survive LES? A View of Perspectives. // J. Fluids Eng. Trans. ASME, 2004, Vol. 127(5), pp. 831839.

30. Huber A. Development and applications of CFD simulations in support of air quality studies involving buildings. // 13th Conf. on the App. of Air Poll. Met./5th AWMA Conf. on the Urban Env., August 25th, 2004.

31. Leschziner M.A. Modelling Engineering Flows with Reynolds Stress Turbulence Closure. // J. Wind Eng. Ind. Aerodyn., 1990, Vol. 35, pp. 21-47.

32. Leschziner M.A. Computational Modelling of Complex Turbulent Flow - Expectations, Reality and Prospects. // J. Wind Eng. Ind. Aerodyn., 1993, Vols. 46-47, pp. 37-51.

33. Leitl B.M., Meroney R.N. Car Exhaust Dispersion in a Street Canyon. // Numerical Critique of a Wind Tunnel Experiments. // J.Wind Eng. Ind. Aerodyn., 1997, Vols. 67\&68, pp. 293-304.

34. Meroney R.N. Wind Tunnel and Numerical Simulation of Pollution Dispersion: A Hybrid Approach. // Paper for Invited Lecture at the Croucher Advanced Study Institute, Hong Kong University of Science and Technology, 6-10 December 2004.

35. Murakami S. Current Status and Future Trends in Computational Wind Engineering. // J. Wind Eng. Ind. Aerodyn., 1997, Vols. 67-68, pp. 3-34.

36. Mochida A., Iizuka S., Tominaga Y., Lun I.Y.F. Up-scaling CWE Models to Include Mesoscale Meteorological Influences. // J. Wind Eng. Ind. Aerodyn., 2011, Vol. 99(4), pp. 187-198.
37. Murakami S. Numerical Simulation of Turbulent Flow Field around Cubic Model: Current Status and Applications of $\mathrm{k}-\mathrm{e}$ model and LES. // J. Wind Eng. Ind. Aerodyn., 1990, Vol. 33(1-2), pp. 139-152.

38. Murakami S., Ooka R., Mochida A.,Yoshida S., Kim S. CFD Analysis of Wind Climate from Human Scale to Urban Scale. // J. Wind Eng. Ind. Aerodyn., 1999, Vol. 81(1-3), pp. 57-81.

39. Oberkampf W.L., Trucano T.G., Hirsch C. Verification, Validation and Predictive Capability in Computational Engineering and Physics. // Appl. Mech. Rev., 2004, Vol. 57(5), pp. 345-384.

40. Richards P.J., Hoxey R.P. Appropriate Boundary Conditions for Computational Wind Engineering Models Using the $\mathrm{k}-\varepsilon$ Turbulence Model. // J. Wind Eng. Ind. Aerodyn., 1993, Vols. 46\&47, pp. 145-153.

41. Richards P.J., Norris S.E. Appropriate Boundary Conditions for Ccomputational Wind Engineering Models Revisited. // J. Wind Eng. Ind. Aerodyn., 2011, Vol. 99(4), pp. 257-266.

42. Roache P.J. Quantification of Uncertainty in Computational Fluid Dynamics. // Annu. Rev. Fluid Mech., 1997, Vol. 29, pp. 123160.

43. Schatzmann M., Leitl B. Issues with Validation of Urban flow and Dispersion CFD models. // J. Wind Eng. Ind. Aerodyn., 2011, Vol. 99, pp. 169-186.

44. Schatzmann M., Rafailidis S., Pavageau M. Some Remarks on the Validation of Small-Scale Dispersion Models with Field and Laboratory Data. // J. Wind Eng. Ind. Aerodyn., 1997, Vols. 67-68, pp. 885-893.

45. Stathopoulos T. Computational Wind Engineering: Past Achievements and Future Challenges. /// J. Wind Eng. Ind. Aerodyn., 1997, Vols. 67-68, pp. 509-532.

46. Stathopoulos T. The Numerical Wind Tunnel for Industrial Aerodynamics: Real or Virtual in the New Millennium? // Wind \& Structures, 2002, Vol. 5, No. 2-4, pp. 193-208. 
47. Tamura T. Towards Practical Use of LES in Wind Engineering. // J. Wind Eng. Ind. Aerodyn., 2008, Vol. 96(10-11), pp. 14511471.

48. Tominaga Y., Iizuka S., Imano M., Kataoka H., Mochida A., Nozu T., Ono Y., Shirasawa T., Tsuchiya N., Yoshie R. Cross Comparisons of CFD Results of Wind and Dispersion Fields for MUST Experiment: Evaluation Exercises by AIJ. // $J$. Asian Archit. Building Eng., 2013, Vol. 12(1), pp. 117-124

49. Xie Z.-T., Castro I.P. Efficient Generation of Inflow Conditions for Large Eddy Simulation of Street-Scale Flows. // Flow, Turbul. Combust., 2008, Vol. 81, pp. 449-470.

\section{СПИСОК ЛИТЕРАТУРЫ}

1. Белостоцкий А.М., Акимов П.А., Афанасьева И.Н. Вычислительная аэродинамика в задачах строительства. - М.: ACB, 2017. - $720 \mathrm{c}$.

2. Попов Н.А. Национальное приложение к ЕN 1991 Еврокод 1. ОАО «НИЦ Строительство». - М.: ЦНИИСК им. В.А. Кучеренко, 2011. - 99 с.

3. Попов Н.А. Рекомендации по уточненному динамическому расчету зданий и сооружений на действие пульсационной составляющей ветровой нагрузки. Госстрой России. - М.: ГУП ЦНИИСК им. В.А. Кучеренко, 2000. - 45 с.

4. Попов Н.А., Богачев Д.С. Воздействие ветра на высотные здания в условиях плотной городской застройки. // Вестник НИЦ Строительство, 2011, №3-4, с. 189-198.

5. Попов Н.А., Лебедева И.В. Изменение №1 к СП 20.13330.2011 «Нагрузки и воздействия», Актуализированной редакции СНиП 2.01.07-85. // Строительная механика и расчет сооружений, 2014, №2(253), c. 67-70.

6. Попов Н.А., Лебедева И.В. Разработка национальных приложений к Еврокодам
EN 1990, EN 1991 с учетом требований российских нормативных документов. // БСТ: Бюллетень строительной техники, 2013, №2(942), c. 37-41.

7. Попов Н.А., Лебедева И.В. Сравнительный анализ Еврокодов EN 1991 и актуализированной редакции СНиП «Нагрузки и воздействия». // Сейсмостойкое строительство. Безопасность сооружений, 2011, №6, c. 17-21.

8. СП 20.13330.2016 Нагрузки и воздействия. Актуализированная редакция СНиП 2.01.07-85* (с Изменением №1). М.: АО «Кодекс», 2017.

9. Изменение №2 к СП 20.13330.2016 «СНИП 2.01.07-85* Нагрузки и воздействия». Утверждено приказом Министерства строительства и жилищнокоммунального хозяйства Российской Федерации от 28 января 2019 г. №49/пр. - М., 2019. - 21 с.

10. Федеральный закон от 29 декабря 2004 г. №190-Ф3 «Градостроительный кодекс Российской Федерации».

11. Ai Z.T., Mak C.M. CFD Simulation of Flow and Dispersion Around Anisolated Building: Effect of Inhomogeneous ABL and Near-Wall Treatment. // Atmos. Environ., 2003, Vol. 77, pp. 568-578.

12. Antipin A.A., Alekhin V.N., Gorodilov S.N., Khramtsov S.V., Noskov A.S. Numerical Simulation of Wind Loads on High-Rise Buildings. // 19th Australasian Fluid Mechanics Conference, Melbourne, Australia 8-11 December 2014, 4 pages.

13. Baker C.J. Wind Engineering - Past, Present and Future. // J. Wind Eng. Ind. Aerodyn., 2007, Vol. 95(9-11), pp. 843-870.

14. Blocken B. 50 years of Computational Wind Engineering: Past, present and future. // J. Wind Eng. Ind. Aerodyn., 2014, Vol. 129, pp. 69-102.

15. Blocken B., Carmeliet J. On the Errors Associated with the Use of Hourly Data in Wind-Driven Rain Calculations on Building Facades. // Atmos. Environ., 2007, Vol. 41 (11), pp. 2335-2343. 
16. British Standard, Loadings for Buildings Part 2: Code of Practice for Wind Loads, Building and Civil Engineering Sector Board, UK, 1995.

17. Castro I.P., Graham J.M.R. Numerical Wind Engineering: the Way Ahead? // Proc. Inst. Civil Eng. - Struct. Build., 1999, Vol. 134(3), pp. 275-277.

18. Cochran L., Derickson R. Aphysical Modeler's View of Computational Wind Engineering. // J. Wind Eng. Ind. Aerodyn., 2011, Vol. 99(4), pp. 139-153.

19. Cowan, Ian R. Castro, Ian P. Robins, Alan G. Numerical Considerations for Simulations of Flow and Dispersion around Buildings. // J. of Wind Eng. and Ind. Aerodynamics, 1997, Vols. 67 \& 68, pp. 535545.

20. Davenport A.G. The Missing Links. // In: Proceedings of the10th International Conference on Wind Engineering, Copenhagen, 1999, pp. 3-15.

21. Di Sabatino S., Buccolieri R., Salizzoni P. Recent Advancements in Numerical Modelling of Flow and Dispersion in Urban Areas: A Short Review. // Int. J. Environ. Pollut., 2013, Vol. 52(3-4), pp. 172-191.

22. Eurocode 1: Basis design and action on structures. Part 1: "Basis design". ENV 1991 1, // CEN, 1994, 232 pages.

23. Ferziger J.H. Approaches to Turbulent Flow Computation: Applications to Flow over Obstacles. // J. Wind Eng. Ind. Aerodyn., 1990, Vol. 35, pp. 1-19.

24. Ferziger J.H. Estimation and Reduction of Numerical Error. // FED vol. 158, In: Proceedings of the Symposium on Quantification of Uncertainty in Computational Fluid Dynamics, ASME Fluid Engineering Division, Summer Meeting, Washington DC, June20-24, 1993, pp. 1-8.

25. Ferziger J.H., Peric M. Computational Methods for Fluid Dynamics. Springer, Berlin, 1996, 356 pages.

26. Fothergill C.E., Roberts P.T. Flow and Dispersion Around Storage Tanks: A Comparison Between Numerical and Wind Tun- nel Studies. // Wind \& Structures, 2002, Vol. 5, No.2-4, pp. 89-100.

27. Hanna S.R. Plume Dispersion and Concentration Fluctuations in the Atmosphere. // Encyclopedia of Environmental Control Technology. Air Pollution Control, 1989, Vol. 2, Gulf Publishing Company, Houston, TX, pp. 547-582.

28. Hargreaves D.M., Wright N.G. On the Use of the $\mathrm{k}-\varepsilon$ Model in Commercial CFD Software to Model the Neutral Atmospheric Boundary Layer. // J. Wind Eng. Ind. Aerodyn., 2007, Vol. 95(5), pp. 355-369.

29. Hanjalic K. Will RANS Survive LES? A View of Perspectives. // J. Fluids Eng. Trans. ASME, 2004, Vol. 127(5), pp. 831839.

30. Huber A. Development and applications of CFD simulations in support of air quality studies involving buildings. // 13th Conf. on the App. of Air Poll. Met./5th AWMA Conf. on the Urban Env., August 25th, 2004.

31. Leschziner M.A. Modelling Engineering Flows with Reynolds Stress Turbulence Closure. // J. Wind Eng. Ind. Aerodyn., 1990, Vol. 35, pp. 21-47.

32. Leschziner M.A. Computational Modelling of Complex Turbulent Flow - Expectations, Reality and Prospects. // J. Wind Eng. Ind. Aerodyn., 1993, Vols. 46-47, pp. 37-51.

33. Leitl B.M., Meroney R.N. Car Exhaust Dispersion in a Street Canyon. // Numerical Critique of a Wind Tunnel Experiments. // J.Wind Eng. Ind. Aerodyn., 1997, Vols. 67\&68, pp. 293-304.

34. Meroney R.N. Wind Tunnel and Numerical Simulation of Pollution Dispersion: A Hybrid Approach. // Paper for Invited Lecture at the Croucher Advanced Study Institute, Hong Kong University of Science and Technology, 6-10 December 2004.

35. Murakami S. Current Status and Future Trends in Computational Wind Engineering. // J. Wind Eng. Ind. Aerodyn., 1997, Vols. 67-68, pp. 3-34.

36. Mochida A., Iizuka S., Tominaga Y., Lun I.Y.F. Up-scaling CWE Models to Include 
Mesoscale Meteorological Influences. // $\mathrm{J}$. Wind Eng. Ind. Aerodyn., 2011, Vol. 99(4), pp. 187-198.

37. Murakami S. Numerical Simulation of Turbulent Flow Field around Cubic Model: Current Status and Applications of $\mathrm{k}-\mathrm{e}$ model and LES. // J. Wind Eng. Ind. Aerodyn., 1990, Vol. 33(1-2), pp. 139-152.

38. Murakami S., Ooka R., Mochida A.,Yoshida S., Kim S. CFD Analysis of Wind Climate from Human Scale to Urban Scale. // J. Wind Eng. Ind. Aerodyn., 1999, Vol. 81(1-3), pp. 57-81.

39. Oberkampf W.L., Trucano T.G., Hirsch C. Verification, Validation and Predictive Capability in Computational Engineering and Physics. // Appl. Mech. Rev., 2004, Vol. 57(5), pp. 345-384.

40. Richards P.J., Hoxey R.P. Appropriate Boundary Conditions for Computational Wind Engineering Models Using the $\mathrm{k}-\varepsilon$ Turbulence Model. // J. Wind Eng. Ind. Aerodyn., 1993, Vols. 46\&47, pp. 145-153.

41. Richards P.J., Norris S.E. Appropriate Boundary Conditions for Ccomputational Wind Engineering Models Revisited. // J. Wind Eng. Ind. Aerodyn., 2011, Vol. 99(4), pp. 257-266.

42. Roache P.J. Quantification of Uncertainty in Computational Fluid Dynamics. // Annu. Rev. Fluid Mech., 1997, Vol. 29, pp. 123160.

43. Schatzmann M., Leitl B. Issues with Validation of Urban flow and Dispersion CFD models. // J. Wind Eng. Ind. Aerodyn., 2011, Vol. 99, pp. 169-186.

44. Schatzmann M., Rafailidis S., Pavageau M. Some Remarks on the Validation of Small-Scale Dispersion Models with Field and Laboratory Data. // J. Wind Eng. Ind. Aerodyn., 1997, Vols. 67-68, pp. 885-893.

45. Stathopoulos T. Computational Wind Engineering: Past Achievements and Future Challenges. /// J. Wind Eng. Ind. Aerodyn., 1997, Vols. 67-68, pp. 509-532.

46. Stathopoulos T. The Numerical Wind Tunnel for Industrial Aerodynamics: Real or Virtual in the New Millennium? // Wind \& Structures, 2002, Vol. 5, No. 2-4, pp. 193-208.

47. Tamura T. Towards Practical Use of LES in Wind Engineering. // J. Wind Eng. Ind. Aerodyn., 2008, Vol. 96(10-11), pp. 14511471.

48. Tominaga Y., Iizuka S., Imano M., Kataoka H., Mochida A., Nozu T., Ono Y., Shirasawa T., Tsuchiya N., Yoshie R. Cross Comparisons of CFD Results of Wind and Dispersion Fields for MUST Experiment: Evaluation Exercises by AIJ. // $J$. Asian Archit. Building Eng., 2013, Vol. 12(1), pp. 117-124

49. Xie Z.-T., Castro I.P. Efficient Generation of Inflow Conditions for Large Eddy Simulation of Street-Scale Flows. // Flow, Turbul. Combust., 2008, Vol. 81, pp. 449-470.

Alexander M. Belostotsky, Corresponding Member of the Russian Academyof Architecture and Construction Sciences, Professor, Dr.Sc.; Director of Scientific Research Center «StaDyO»; Professor of Department of Structures, Buildings and Facilities, Russian University of Transport» (RUT -MIIT); Professor of Department of Architecture and Construction, Peoples' Friendship University; Professor of Department of Building Structures and Computational Mechanics, Peoples' Friendship University of Russia; Professor of Irkutsk National Research Technical University; office 810, 18, 3ya Ulitsa Yamskogo Polya, Moscow, 125040, Russia; phone +7 (499) 706-88-10;

E-mail: amb@stadyo.ru.

Pavel A. Akimov, Full Member of the Russian Academy of Architecture and Construction Sciences (RAACS), Professor, Dr.Sc.; Executive Scientific Secretary of Russian Academy of Architecture and Construction Sciences; Vice-Director for Science Activities, Scientific Research Center "StaDyO"; Professor of Department of Architecture and Construction, Peoples' Friendship University of Russia; Professor of Department of Structural Mechanics, Tomsk State University of Architecture and Building; 24, Ul. Bolshaya Dmitrovka, 107031, Moscow, Russia; phone +7(495) 625-71-63; fax: +7 (495) 650-27-31; E-mail: akimov@raasn.ru,pavel.akimov@gmail.com.

Irina N. Afanasyeva, Ph.D., Senior Engineer of Scientific Research Center "StaDyO"; Master's Degree Student, University of Florida (USA); office 810, 18, 3ya Ulitsa Yamskogo Polya, Moscow, 125040, Russia; 
phone +7 (499) 706-88-10,

E-mail: irina.n.afanasyeva@gmail.com.

Белостоцкий Александр Михайлович, членкорреспондент РААСН, профессор, доктор технических наук; генеральный директор ЗАО «Научноисследовательский центр СтаДиО»; профессор кафедры «Строительные конструкции, здания и сооружения» Российского университета транспорта (МИИТ); профессор Департамента архитектуры и строительства Российского университета дружбы народов; профессор кафедры строительных конструкций и вычислительной механики Пермского национального исследовательского политехнического университета; профессор Иркутского национального исследовательского технического университета; 125040, Россия, Москва, ул. 3-я Ямского Поля, д.18, офис 810; тел. +7 (499) 706-88-10; e-mail: amb@stadyo.ru.

Акимов Павел Алексеевич, академик Российской академии архитектуры и строительных наук (РАACH), профессор, доктор технических наук; главный ученый секретарь Российской академии архитектуры и строительных наук; заместитель генерального директора по науке ЗАО «Научно-исследовательский центр СтаДиО»; профессор Департамента архитектуры и строительства Российского университета дружбы народов; профессор кафедры строительной механики Томского государственного архитектурно-строительного университета; 107031, г. Москва, ул. Большая Дмитровка, д. 24, стр. 1; тел. +7(495) 625-71-63;

факс+7 (495) 650-27-31; E-mail: akimov@raasn.ru, pavel.akimov@gmail.com.

Афанасьева Ирина Николаевна, кандидат технических наук, ведущий инженер-расчетчик ЗАО «Научноисследовательский центр СтаДиО» (ЗАО НИЦ «СтаДиО»); магистрант Университета Флориды (США); 125040, Россия, г. Москва, ул. 3-я Ямского Поля, д.18, 8 этаж, офис 810, тел. +7 (495) 706-88-10,

E-mail: irina.n.afanasyeva@gmail.com. 